\title{
Exploration of English Course Teaching Based on the new Method of Online SPOC Teaching
}

\author{
Guo Qin \\ School of Foreign Languages, Tianhe College of Guangdong Polytechnic Normal University, \\ Guangzhou510000, China. \\ 369002137@qq.com
}

Keywords: Small Private Course Online; English; course teaching.

\begin{abstract}
English teaching is an important basic course of higher education teaching, it has application and practical characteristics, in view of the current English teaching mode in colleges is obsolete, cannot effectively improve students' practical ability and English self-learning ability, combined with SPOC (Small Private Online Course) small scale restricted online course learning mode, explore a new English teaching method. The small scale, limited online course learning method is applied in English teaching reform practice, combined with the online SPOC teaching mode in Colleges and universities teaching, learning resources are published on the platform through online course platform, students can arrange learning content according to their own time schedule, online information feedback, interaction between teachers and students, promote knowledge internalization. Through teaching reform, classroom teaching mode is innovated, and it can stimulate the enthusiasm and vitality of the classroom teaching, the effectiveness and quality of English teaching can be ensured.
\end{abstract}

\section{Introduction}

With the development of global integration and integration of language and culture of the world, put forward higher requirements of practical application ability of English teaching and learning. In Chinese higher education system, English teaching is a basic course of education, colleges and universities attach great importance to English education to a very high level ${ }^{[1]}$. Society puts forward higher requirements for colleges and universities students' English application ability and level, the traditional English teaching mode has been unable to meet the needs of social development. To improve college students' English application and practical ability, and improve their English language proficiency, it is necessary to explore the reform of English teaching mode. By shaping the English practice teaching operation environment, English proficiency is trained from the actual environment, through the study of scientific and effective English teaching methods, and traditional classroom teaching mode is reformed. It has important significance for improving English application quality and ability of students ${ }^{[2]}$.

SPOC teaching is taken as a new teaching mode and teaching methods, it can be introduced into the English education, SPOC is a small scale restricted online teaching mode, the current SPOC teaching cases, mainly set for the study of two types of students and students in the walls, the former is a combination of blended learning mode of classroom teaching and online teaching, in the university campus classroom, using MOOC video lectures (or at the same time using the online evaluation function), flipping the classroom is implemented, it has the very good practical effect in College English teaching, because of English teaching through the SPOC teaching mode, teachers can free to set and control the progress, rhythm and scoring system of the course according to their own the preferences and needs of students, the students can watch the video lectures, learning 
rhythm is designated self for course materials, homework, participate in online discussions, etc ${ }^{[3]}$. Therefore, SPOC teaching method has strong practical and interactive features in the teaching of English Curriculum in the course of application especially practical effect, with the reform of the teaching mode of College English curriculum development, the introduction of SPOC teaching methods will become a new trend of College English teaching mode. The new mode and method of English curriculum is studied based on SPOC teaching method in this paper, through the SPOC teaching method, redefining the role of teachers, the teaching mode of innovative, , according to the needs of students to integrate various online and physical resources, the innovation of classroom teaching mode is explored, to stimulate the enthusiasm and vitality of classroom teaching of teachers, through SPOC teaching, emphasize students complete and in-depth learning experience, improve the completion rate of course, resulting in a more effective English teaching and after-school learning effect.

\section{Analysis of the characteristics and the current situation of English Teaching}

English education is a fundamental language curriculum education, it has the function related to the students' scientific research field in the future, the export trade, travel abroad, learning and communication in life. Due to the rapid updating of the content of English curriculum, the traditional textbook education cannot meet the needs of students, so it is urgent to study the reform of English teaching methods. The teaching content of the discipline of English Curriculum in the vocabulary of frequently updated coverage and articles from British and American newspapers and magazines the vocabulary, English learning content is changing every day, therefore, in English learning and education, there is a need for better methods of teaching. The teaching methods of College English teaching methods main contain teaching methods of MOOC online and face-to-face type, along with the development of blowout large-scale online courses of MOOC, its limitations have become increasingly prominent, the traditional MOOC teaching mode of College English teaching is to evaluate the effect of learning interaction of students and students, the high registration rate, low success rate, therefore, after the development of the MOOC tide gradually ease, combined with the University face-to-face courses, the SPOC courses is appeared. Combined with SPOC online teaching methods, the English teaching reform is taken, and in the classroom to teach the students application of English knowledge and learning methods as much as possible, in the language environment to master English knowledge and skills. Before the exploration of SPOC teaching methods, the characteristics of English teaching are analysed. English teaching is the main course of study, evaluation content is more difficult times stronger, the changing characteristics of word change and the content of the textbooks so in English teaching methods in the exploration process, it needs to follow the characteristics of the times, collection of the latest domestic and foreign language teaching materials and literature articles, English Vocabulary learning and training read the article. By optimizing the allocation of teaching resources, improve the English classroom teaching interesting, through the development of multimedia teaching and SPOC teaching mode, and improve classroom teaching quality and efficiency ${ }^{[4]}$.

At present, generally consists of two parts of College English teaching is a practical English Teaching for the first grade, mainly based on the English expression of daily life and general work scenarios, including written translation and syntax based on six parts, it is arranged on the third semester or fourth semesters of professional English, mainly based on the special vocabulary and expression the professional involved, a total of 160 hours (including 96 hours of practical English and professional English for 64 hours). Practical English class teaching mode is taken, mainly in classroom teaching materials, at the same time with the university English ability test pretco-a or 
TOEIC bridge test certificate examination counselling. Professional English and other professional teachers are responsible for teaching, mainly in the professional vocabulary and expression input. Students are required after learning all the English course, it can express and master the skill of daily communication, reading the daily application and technical articles, general business conditions can write letters, and can do a simple translation of the professional knowledge of the profession based on grammar and vocabulary use basic right ${ }^{[5]}$. However, the current curriculum and teaching content is difficult to fully achieve the teaching requirements, due to the concept of curing and the teaching system is not perfect, the current college English classroom teaching also has many outstanding issues need to be resolved, the main reason and embodied in the following aspects:

Firstly, Student foundation is uneven in quality. As everyone knows, the proportion of higher vocational students every year are expanding, and this part of the students, through the investigation of the students found that most of the students of the English foundation is weak, some students even admitted their English is almost equal to zero based situation. At the same time, from the part of secondary vocational school students, because of its curriculum setting occupation thus reducing the basic course proportion, leading students in the guiding ideology of science and technology of the priority to the tone of English teaching goals in Higher Vocational English teaching to make it slow.

Secondly, English teaching content and curriculum system is not perfect. Curriculum practice is weak, rely mainly on classroom input and situational teaching of college students, especially the applied undergraduate students have strong ability, and the theory of acquisition ability weaker. The lack of language environment of foreign language learning, mainly rely on the theory of input and the setting of the role of role-playing exercises. However, the practice cannot arouse the students' practical experience, which is necessary to improve the students' practical ability. And the current college English teaching is more oriented to the university English four, six level for the purpose of teaching, the degree of depth of quality education of English is not high, systematic and integrity requirements for English teaching content and the system is not standard, teaching contents and methods need to be further optimized, in order to improve the efficiency and level of College English classroom teaching.

Thirdly, the allocation of teachers' strength in College English teaching is not enough, and the school is not enough emphasis on English teaching. The allocation of teachers in College English teaching is uneven, the quality of teachers is not a requirement, the allocation of university English teachers have low structure and ability and quality problems, resulting in the classroom teaching efficiency is not high.

Fourthly, the teaching resources allocation is not reasonable, the teaching method is single. The current college English teaching is mainly paper teaching methods of introducing multimedia and audio-visual teaching is not deep enough, more emphasis on the teaching of English reading and vocabulary of English training, English ability is not high enough to affect the efficiency of classroom teaching.

\section{A new method of online SPOC Teaching}

In view of the existing problems in the teaching of College English, the teaching reform is explored, and the teaching mode of online SPOC "flipped classroom" is adopted to promote the transformation of teaching ideas and the improvement of teaching methods. SPOC is proposed by Professor Armando Fox of the University of California at Berkeley, SPOC as a new thing, the concept is to solve the MOOC problem in learning, such as limiting the scale of students, 
interaction between teachers and students, promote the internalization of knowledge. In the SPOC teaching mode under the day before class, the teacher through the online course platform, the learning resources released on the platform, students through learning and processing homework learning behaviour intake target knowledge on the network platform, and through the line of flipping the classroom, group activities, seminars etc. internalization and expand knowledge, thus effectively master learning objectives. SPOC created a college of flipping the classroom teaching mode, it created a hybrid teaching environment a combination of online and offline, students can conduct online learning at any time according to their time and interest, and submit online homework, online feedback, to bring enlightenment to college English teaching mode. SPOC will be part of a network learning environment for students learning space development, relying on the existing MOOC platform of online teaching, through the application of appropriate learning techniques and appropriate learning style fit, to achieve the optimization of the learning effect. A new method of teaching online SPOC to the traditional way of studying the advantages and advantages of network learning combined skilfully, which played the leading role of teachers to guide and inspire and monitoring the teaching process, the enthusiasm and initiative of the principles and reflects the students as the main body of the study. The SPOC curriculum is based on a small scale of specific people, it is easy to serve the university teaching, which contains a wealth of media resources to meet the needs of individual students to learn, to attract the participation of many learners. The hybrid learning model, based on SPOC online course resources, expand learning platform or the reality in the original MOOC environment, and the integration of autonomous learning, inquiry learning, cooperative learning, reflective learning and other learning methods, to achieve a multi collaborative curriculum development team, teachers and learners. The online SPOC teaching method is dynamic, open, complex and diversified. The effectiveness of the application of SPOC teaching method in English teaching is mainly reflected as follows:

(1) The online learning function of SPOC teaching mode can reduce the burden of teachers, and at the same time strengthen the concept of interactive learning and self-learning in English teaching;

(2) The video content of SPOC's previous course lectures are rich and dense, so students can pause and review any knowledge points, so it is a very efficient way to transmit information;

(3) SPOC allows teachers to return to the campus, return to a small online classroom, so that students can be exposed to the English language application of new articles and new words excited;

(4) In the SPOC classroom, the teacher is the guide and facilitator, they organize the students to group discussion, provide individual guidance for them, the problem to solve. The SPOC curriculum brings the challenge to the excellent students;

(5) Students (through lectures video) accept the world first-class teaching resources, because EDX play SPOC in its open source platform, teachers no need to install any software, only need a browser, which can be customized according to the needs of the curriculum, SPOC emphasizes students complete and in-depth learning experience, which is conducive to improve the utilization efficiency of course of study efficiency and resources.

\section{Design of English teaching model based on SPOC}

With the new method of online SPOC, teaching English course mode optimization is designed, it focuses on the curriculum resources planning, curriculum design, teaching strategy, SPOC curriculum resources development and implement of teaching and evaluation etc.

(1) Curriculum resource planning. To ensure the integrity of the SPOC online learning in the teaching practice of English curriculum, in the design of SPOC course, need planning curriculum resources in online learning resources planning, need to follow the principles of initiative, sociology 
principle and systematic principle. The basic characteristics of teacher learning and prior knowledge in understanding to determine the starting point of teaching, teaching objectives or original teaching objectives based on the teaching material in the curriculum design and development, and according to the teaching target classification learning content, distinguish for online and offline learning content unit, to ensure that students can grasp the method in learning English, to adopt appropriate methods of discipline rule, studies on English subject nature. The knowledge points in English course in micro class and other forms in the network platform, students complete the relevant knowledge in learning will set the corresponding exercises to help students understand and grasp the knowledge points in SPOC online learning environment, students will not be subject to space and time limit, can be arranged according to their own time to learn whenever and wherever possible the corresponding courses.

(2) Teaching design. The teaching of College English curriculum design mainly from learning goal elaboration, difficulty analysis, learner characteristic analysis and teaching strategy are analysed, through online SPOC learning, make teaching plan scientifically, and build the system of integrated knowledge system for students, in order to ensure the development of the SPOC curriculum can improve study enthusiasm, stimulate students' interest in learning, and to cultivate students' autonomous learning ability as the basic starting point and foothold, to improve the traditional classroom teaching effect and quality, encourage learners' active participation and independent study and cooperative learning, cultivate students' ability to embody constructivism the role of context and the importance of learning reflection. Through the SPOC online English curriculum learning, can improve students ability according to the research needs, through interviews, literature search, questionnaire survey, field observation and analysis, data statistics and experimental study of a variety of ways such as collecting the facts, try to use in the production course of vivid animation and rich and colourful pictures to help students understand and memorize vocabulary the phrase, or to guide students to practice, the concept to concrete things instead of abstract, it should avoid simple text presentation and vocabulary memory.

(3) Teaching strategy formulation. Select the appropriate teaching strategies is a key role in improving the quality of teaching and promote students' learning, different teaching strategies will play different teaching effect, in the SPOC study, to the question of introducing, creating real situations for the students in the course of the initial, guide students into the scene, arouse the curiosity of students in the imperceptibly and fully mobilize the enthusiasm of students, develop teaching strategies to enhance the enthusiasm of the students, for the development of students' online learning courses, so that students in the shortest time with the highest effective way to master knowledge.

(4) SPOC curriculum resources development. SPOC curriculum resources development blended learning process mainly includes 4 processes: (a) learning needs identification and definition; (b) the teaching plan and measurement strategy; (c) the development or selection of teaching contents; (d) implementation plan and implementation of teaching. SPOC curriculum resources development mode has three kinds, respectively is the introduction, construction, transformation, namely the introduction of high-quality MOOC curriculum resources, build its own SPOC curriculum, self-built resources to curriculum resources, while the introduction of MOOC resources should pay attention to meet the degree of its course content and the curriculum requirements and is in accordance with the syllabus of College English course. To understand the professional and all levels of students for English learning requirements, it can allocate time and energy to the students through the investigation. In the process of development, according to the characteristics of the 
knowledge points, flexible selection of the presentation, so that the curriculum to maintain a permanent flexibility, so as to ensure the continuous learning of students.

(5) Teaching implementation and evaluation. In the evaluation of English teaching, the curriculum resources of formative assessment and summative evaluation, optimization and adjustment of teaching contents according to the review gives opinions and suggestions and curriculum resources, to achieve higher standards to guide and promote the students' learning in College English course. Through the professional occupation and job demand for research, summed up the professional requirements for the students' English ability, so as to find out the required students between existing English skills and the future work of the English skills gap, clear course orientation and core competence, and provide scientific basis for formulating the teaching plan and teaching contents ready.

In the exploration of SPOC mode, the whole learning process is divided into three parts: online learning, classroom instruction and curriculum practice. Online learning is the process of knowledge preparation and input. Teachers through the network platform to publish learning plans and learning tasks, requiring students to choose the appropriate resources in accordance with the list of independent tasks to learn and complete the corresponding exercises. The teacher through the network platform supervision and statistics, the basic condition of students' learning, summed up the students' learning problems and difficulties in the process, to explain and guide in the course of teaching. In the guidance process, first go and difficulty answering counselling, and then according to the learning objectives set the learning task, let the students finish the task in the process of knowledge internalization and integration, the output in the display task result, according to the teachers' vocabulary practice, basic sentence type, text comprehension, grammar, dialogue etc. set a task such as text or games, role-playing, vocabulary competition etc. Students complete a series of tasks in an independent or cooperative manner, the practice of language communication activities. Third, the curriculum practice will be in the form of curriculum practice week. After completing all the learning tasks, students are required to demonstrate their communicative competence in the last two weeks of the course. English teachers design style show activities, such as English, English drama, poster design of the professional English product promotion, to further students' learning results of three-dimensional evaluation, but also through a series of interesting activities to improve students' learning enthusiasm.

\section{Conclusion}

SPOC online teaching mode provides a new model and platform for College English teaching, combining classroom teaching with SPOC education technology, through the English SPOC course design, the teaching content integration and design ability is strengthened in further, the three-in-one blended learning model is improved in "Knowledge module learning, small class counselling internalization, curriculum practice". The curriculum content is modularized, the teaching resources are three-dimensional, the teaching organization is flexible, and the practice teaching is active. The students' autonomous learning ability is improved greatly. In the SPOC teaching mode, the ideal teaching goal of imparting knowledge outside the classroom, and the knowledge is internalized in the class is realized. The effectiveness of the teaching English is improved. 


\section{Acknowledgments}

This project is supported by A Study on the Efficiency of Second Language Acquisition Based on SPOC Foreign Language Teaching Model (Guangdong Higher Education letter [20 17] 45) 2016GXJK232.

\section{References}

[1]. LIN Ying, LITong, DU Lei. Innovative design course project driven teaching method to explore [J]. Computer education, 2015 (9):72-74.

[2]. ZHANG Zhou, WU Xin. Based on SPOC and TBLT's "Business English" teaching research paradigm of Civil Aviation [J]. Bulletin of Science and Technology, 2015,31 (4):261-264.

[3]. GUO Qin. From MOOC to SPOC: the new trend of online education and Its Enlightenment to local Applied Universities [J]. Journal of Taiyuan City Vocational College, 2015,03:103-105.

[4]. ZHENG Qi, YANG Zhujun. SPOC: combined with the integration of College Teaching Innovation [J]. Physics and Engineering, 2014,24 (1):15-18.

[5]. LU Xinghua, FAN Tailin, XIE Zhenhan. Embedded System Design of Multi-Mode Intelligent Control Based on ARM [J]. Computer \& Digital Engineering, 2016,44 (4): 667-670,674.

[6]. LIU, Lei, Study on the Computer Aided English Instruction from the Learning Perspective of Constructivism [C]. ICETEM 2015 (3): 1-6. 